\title{
THE SYNTHESIS AND PHYSICOCHEMICAL PROPERTIES OF 2-(5-METHOXY-PHENYL-1H-1,2,4-TRIAZOLE-3-YLTHIO) ACETONITRILES AND THEIR IMINOETHERS
}

\author{
Yu.G.Sameluk, A.G.Kaplaushenko \\ Zaporizhzhya State Medical University, \\ 69035, Mayakovsky avenue 26, Zaporizhzhya, Ukraine. E-mail: zsmu@zsmu.zp.ua
}

Key words: 1,2,4-triazoles; nitriles; iminoethers

\begin{abstract}
With the purpose of further search of biologically active substances among 5-(2-, 3-, 4-methoxyphenyl, 3,4,5trimethoxyphenyl)-3-thio-1,2,4-triazoles and their derivatives 10 new compounds have been obtained. Acetonitrilothio-1,2,4-triazoles have been synthesized by alkylation of 5-(2-, 3-, 4-methoxyphenyl and 3,4,5-trimethoxyphenyl)-3-thio-1,2,4-triazoles with halogenonitriles; the primary computer pharmacological screening has shown that the class of compounds mentioned can show such types of the pharmacological activity as antitumor, antiinflammatory and antioxidant ones. Alkylation of 5-R-1,2,4-triazole-3-thiols has been carried out in the medium of anhydrous alcohol or aprotic solvents. It has been found that replacement of the alcoholic solvent by the aprotic one increases the quantitative yield of 5-R-1,2,4-triazol-3-thioacetonitrile; in aprotic solvents the presence of impurities of alkaline hydrolysis products is not practically observed. Iminoethers of 2-(5-(2-, 3-, 4-methoxyphenyl and 3,4,5-trimethoxyphenyl)-1H-1,2,4-triazole-3-ylthio)acetatic acids have been synthesized by saturation of 2-(5-(2-, 3-, 4-methoxyphenyl and 3,4,5-trimethoxyphenyl)-1H-1,2,4-triazol-3-ylthio)acetonitriles with the flow of dry in the alcoholic medium when constant cooling the reaction mixture to $-5^{\circ} \mathrm{C}$. It has been found by the method of HPLC/DAD-MS that the qualitative yield of the target product depends on the maintenance of the temperature mode of the reaction mixture. The structure and individuality of the molecules of the substances synthesized have been proven by the method of ${ }^{1} H$ NMR-spectroscopy and HPLC/DAD-MS.
\end{abstract}

СИНТЕЗ I ФІЗИКО-ХІМІЧНІ ВЛАСТИВОСТІ 2-(5-МЕТОКСИФЕНІЛ-1Н-1,2,4-ТРИАЗОЛ-3-ІЛТІО)АЦЕТОНІТРИЛIВ TA ÏХ IMIHOEФIPIB

Ю.Г.Самелюк, А.Г.Каплаушенко

Ключові слова: 1,2,4-триазоли; нітрили; іміноефріри

3 метою подальшого пошуку біологічно активних речовин серед 5-(2-, 3-, 4-метоксифеніл, 3,4,5-триметоксифеніл)-3-тіо-1,2,4-триазолів та їх похідних було отримано 10 нових сполук. Шляхом алкілування 5-(2-, 3-, 4-метоксифеніл, 3,4,5-триметоксифеніл)-3-тіо-1,2,4-триазолів галогенонітрилами були синтезовані ацетонітрилтіо-1,2,4-триазоли. Первинний комп'ютерний фрармакологічний скринінг показав, що цей клас сполук може проявляти такі види фрармакологічної активності, як протипухлинна, протизапальна і антиоксидантна. Алкілування 5-R-1,2,4-триазол-3-тіолів проводили у безводному спиртовому середовищі або апротонних розчинниках. Встановлено, що заміна спиртового розчинника на апротонний збільшує кількісний вихід 5-R-1,2,4-триазол-3-тіоацетонітрилу; у апротонних розчинниках також практично не спостерігається присутність домішок продуктів лужного гідролізу. Синтезовано іміноесріри 2-(5-(2-, 3-, 4-метоксифеніл, 3,4,5-триметоксифеніл)-1Н-1,2,4-триазол-3-ілтіо)ацетатних кислот шляхом насичення 2-(5-(2-, 3-, 4-метоксифеніл, 3,4,5-триметоксифеніл)-1Н-1,2,4-триазол-3-ілтіо) ацетонітрилів струмом сухого хлористого водню у відповідному спиртовому середовищі при постійному охолодженні реакційної суміші до $-5^{\circ} \mathrm{C}$. Методом ВЕРХ/ДМД-МС встановлено, що вихід цільового продукту залежить від витримки температурного режиму реакційної суміші. Структуру і індивідуальність молекул синтезованих речовин встановлено методами ${ }^{1} \mathrm{H}$ ЯМР-спектроскопії і ВЕРХ/ДМД-МС. СИНТЕЗ И ФИЗИКО-ХИМИЧЕСКИЕ СВОЙСТВА 2-(5-МЕТОКСИФЕНИЛ-1Н-1,2,4-ТРИАЗОЛ-3-ИЛТИО)АЦЕ-
ТОНИТРИЛОВ И ИХ ИМИНОЭФИРОВ

Ю.Г.Самелюк, А.Г.Каплаушенко

Ключевые слова: 1,2,4-триазолы; нитрилы; иминоэфиры

С целью дальнейшего поиска биологически активных веществ среди 5-(2-, 3-, 4-метоксифренил, 3,4,5-триметоксифенил)-3-тио-1,2,4-триазолов и их производных были получены 10 новых соединений. Путем алкилирования 5-(2-, 3-, 4-метоксифенил, 3,4,5-триметоксифенил)-3-тио-1,2,4-триазолов галогеннитрилами были синтезированы ацетонитрилтио-1,2,4-триазолы. Первичный компьютерный фрармакологический скрининг показал, что данный класс соединений может проявлять такие виды фрармакологической активности, как противоопухолевая, противовоспалительная и антиоксидантная. Алкилирование 5-R-1,2,4-триазол-3-тиолов проводили в безводной спиртовой среде или апротонных растворителях. Установлено, что замена спиртового растворителя на апротонный увеличивает количественный выход 5-R-1,2,4-триазол-3-тиоацетонитрила; в апротонных растворителях также практически не наблюдается присутствие примесей продуктов щелочного гидролиза. Синтезированы иминоэфиры 2-(5-(2-, 3-, 4-метоксифенил, 3,4,5-триметоксифенил)-1Н-1,2,4-триазол-3-илтио)ацетатных кислот путем насыщения 2-(5-(2-, 3-, 4-метоксифенил, 3,4,5-триметоксифенил)-1Н-1,2,4-триазол-3-илтио)ацетонитрилов током сухого хлористого водорода в соответствующей спиртовой среде при постоянном охлаждении реакционной смеси до $-5^{\circ} \mathrm{C}$. Методом ВЭЖХ/ДМД-МС установлено, что выход целевого продукта зависит от выдержки температурного режима реакционной смеси. Структура и индивидуальность молекул синтезированных веществ установлены методами ${ }^{1} \mathrm{H}$ ЯМР-спектроскопии и ВЭЖХ/ДМД-МС. 
A considerable interest is caused by the synthesis of biologically active compounds; among them there are substances several times exceeding their out-of-date analogues by action and, in addition, having lower indexes of acute and chronic toxicity. One of the classes of such compounds are derivatives of triazoles [16] used as original drugs with the antibacterial, neuroleptic, hypotensive and spasmolytic activity, and they are cardiac stimulants. The certain interest is also caused by synthetic medicines containing the nitrile group such as letrozole, anastrozole [6] used in modern medical practice as antitumor agents.

At the Physical and Colloidal Chemistry Department of the Zaporizhzhya State Medical University the investigations for searching the biologically active substances among 5-(2-, 3-, 4-methoxyphenyl and 3,4,5-trimethoxyphenyl)-3-thio-1,2,4-triazoles and their derivatives are being conducted. Earlier the corresponding 2-hydrazinocarbothioamides were obtained by interaction of hydrazides of 2-, 3-, and 4methoxy- and 3,4,5-trimethoxybenzoic acids with potassium thiocyanate in the acidic medium; subsequently, 2-hydrazinocarbothioamides were cyclized when heating for $1 \mathrm{~h}$ under the action of 2 mole/l sodium hydroxide solution; 5-(2-, 3-, 4-methoxyphenyl)-1,2,4triazole-3-thiols and 5-(3,4,5-trimethoxyphenyl)-1,2,4triazole-3-thiol were obtained with the high yields [7] (Fig. 1).

At the present stage of our research acetonitrilothio-1,2,4-triazoles have been synthesized by alkylation of 5-(2-, 3-, 4-methoxyphenyl and 3,4,5-trimethoxyphenyl)-3-thio-1,2,4-triazoles with halogenonitriles; the primary computer pharmacological screening has shown that the class of compounds mentioned can show such types of the pharmacological activity as antitumor, anti-inflammatory and antioxidant ones.
Alkylation of 5-R-1,2,4-triazole-3-thiols was carried out in the medium of anhydrous alcohol or aprotic solvents with addition of $\Theta$-chloroacetonitrile and the equimolar amount of alkali when heating the reaction mixture to the temperature of $60-65^{\circ} \mathrm{C}$; whereupon forming the precipitate of the expected reaction product was observed. After filtration the precipitate was washed with ether (Fig. 2).

When studying the conditions of obtaining the target product the successful attempt of thiol alkylation without addition of an alkaline agent was made, and the corresponding hydrochloric salt was formed. The pure product was isolated with anhydrous sodium acetate. Thus, the samples of the compounds synthesized did not give the melting point depression.

Individuality of the corresponding substances has been proven by the method of HPLC/DAD-MS. Descriptions of ${ }^{1} \mathrm{H}$ NMR-spectra of the compounds obtained, some of their physical and chemical properties and the elemental composition are presented in Table 1 and 2.

It has been found that replacement of the alcoholic solvent by the aprotic one increases the quantitative yield of 5-R-1,2,4-triazol-3-thioacetonitrile; in aprotic solvents the presence of impurities of alkaline hydrolysis products is not practically observed (in the case of obtaining the target substances with the equimolar amount of alkali).

It should be noted that the highest yield was observed for compounds contained the 4-methoxyphenyl and 3,4,5-trimethoxyphenyl substituent at $\mathrm{C}^{5}$ atom of the triazole ring (Table 1 , compounds 3,4 ). The lowest yield was observed for compound 2 (Table 1 ) with the 2-methoxyphenyl substituent.

In the ${ }^{1} \mathrm{H}$ NMR-spectra of the compounds of 2-(5(2-,3-,4-methoxyphenyl, 3,4,5-trimethoxyphenyl)-1H-<smiles>[R]C(=O)NNC(=O)NNC(N)=S</smiles>

$$
\mathrm{R}=\mathrm{C}_{6} \mathrm{H}_{4} \mathrm{OCH}_{3}-2, \mathrm{C}_{6} \mathrm{H}_{4} \mathrm{OCH}_{3}-3, \mathrm{C}_{6} \mathrm{H}_{4} \mathrm{OCH}_{3}-4, \mathrm{C}_{6} \mathrm{H}_{2}\left(\mathrm{OCH}_{3}\right)_{3}-3,4,5
$$

Fig. 1. The scheme of obtaining 5-R-1,2,4-triazol-3-thiols.

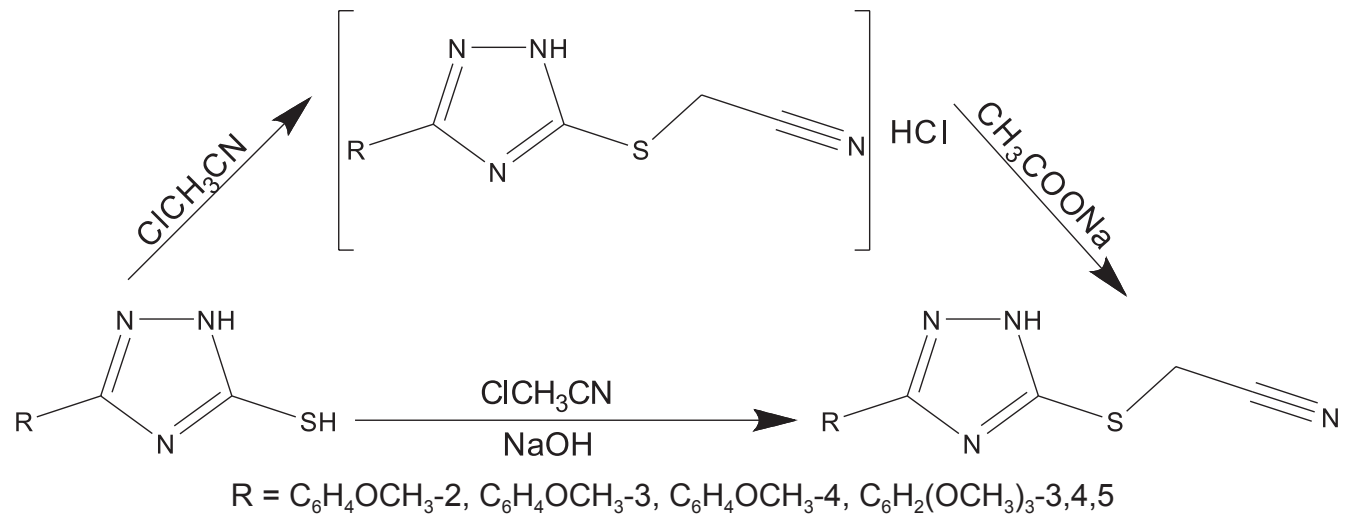

Fig. 2. The scheme of obtaining 5-R-1,2,4-triazol-3-thioacetonitriles. 
Physical and chemical constants of the compounds synthesized<smiles>[R]c1n[nH]c([R])n1</smiles>

\begin{tabular}{|c|c|c|c|c|c|c|}
\hline No. & $\mathrm{R}_{1}$ & $\mathrm{R}_{2}^{+}$ & M.p., ${ }^{\circ} \mathrm{C}$ & $\begin{array}{l}\text { Gross } \\
\text { formula }\end{array}$ & $\begin{array}{l}\text { Yield, } \\
\%\end{array}$ & 'H NMR (ס, m.p., TMS) \\
\hline 1 & $\mathrm{C}_{6} \mathrm{H}_{4} \mathrm{OCH}_{3}-2$ & $\mathrm{SCH}_{2} \mathrm{CN}$ & 164-165 & $\mathrm{C}_{11} \mathrm{H}_{10} \mathrm{~N}_{4} \mathrm{OS}$ & 87 & $\begin{array}{l}\text { 7.04-7.95 }\left(4 \mathrm{H}, \mathrm{m}, \mathrm{C}_{6} \mathrm{H}_{4}\right), 4.40(2 \mathrm{H}, \mathrm{s} \\
\left.\mathrm{S}-\mathrm{CH}_{2}\right), 3.82\left(3 \mathrm{H}, \mathrm{c}, \mathrm{O}-\mathrm{CH}_{3}\right)\end{array}$ \\
\hline 2 & $\mathrm{C}_{6} \mathrm{H}_{4} \mathrm{OCH}_{3}-3$ & $\mathrm{SCH}_{2} \mathrm{CN}$ & $178-180$ & $\mathrm{C}_{11} \mathrm{H}_{10} \mathrm{~N}_{4} \mathrm{OS}$ & 52 & $\begin{array}{l}\text { 7.02-7.97 }\left(4 \mathrm{H}, \mathrm{m}, \mathrm{C}_{6} \mathrm{H}_{4}\right), 4.43(2 \mathrm{H}, \mathrm{s}, \\
\left.\mathrm{S}-\mathrm{CH}_{2}\right), 3.77\left(3 \mathrm{H}, \mathrm{s}, \mathrm{O}-\mathrm{CH}_{3}\right)\end{array}$ \\
\hline 3 & $\mathrm{C}_{6} \mathrm{H}_{4} \mathrm{OCH}_{3}-4$ & $\mathrm{SCH}_{2} \mathrm{CN}$ & $160-162$ & $\mathrm{C}_{11} \mathrm{H}_{10} \mathrm{~N}_{4} \mathrm{OS}$ & 90 & $\begin{array}{l}\text { 7.05-7.93 }\left(4 \mathrm{H}, \mathrm{m}, \mathrm{C}_{6} \mathrm{H}_{4}\right), 4.44(2 \mathrm{H}, \mathrm{s} \\
\left.\mathrm{S}-\mathrm{CH}_{2}\right), 3.80\left(3 \mathrm{H}, \mathrm{s}, \mathrm{O}-\mathrm{CH}_{3}\right)\end{array}$ \\
\hline 4 & $\mathrm{C}_{6} \mathrm{H}_{2}\left(\mathrm{OCH}_{3}\right)_{3}-3,4,5$ & $\mathrm{SCH}$ & 170-171 & $\mathrm{C}_{13} \mathrm{H}_{14} \mathrm{~N}_{4} \mathrm{O}_{3} \mathrm{~S}$ & 86 & $\begin{array}{l}6.83\left(2 \mathrm{H}, \mathrm{s}, \mathrm{C}_{6} \mathrm{H}_{2}\right), 3.98\left(2 \mathrm{H}, \mathrm{s}, \mathrm{S}-\mathrm{CH}_{2}\right), \\
3.87\left(3 \mathrm{H}, \mathrm{s}, \mathrm{O}-\mathrm{CH}_{3}\right), 3.85(3 \mathrm{H}, \mathrm{s}, \\
\left.\mathrm{O}-\mathrm{CH}_{3}\right), 3.80\left(3 \mathrm{H}, \mathrm{s}, \mathrm{O}-\mathrm{CH}_{3}\right)\end{array}$ \\
\hline 5 & $\mathrm{C}_{6} \mathrm{H}_{4} \mathrm{OCH}_{3}-3$ & & $88-90$ & $\mathrm{C}_{12} \mathrm{H}_{14} \mathrm{~N}_{4} \mathrm{O}_{2} \mathrm{~S}$ & 67 & $\begin{array}{l}\text { 6.97-7.93 }\left(4 \mathrm{H}, \mathrm{m}, \mathrm{C}_{6} \mathrm{H}_{4}\right), 4.35(2 \mathrm{H}, \mathrm{s}, \\
\left.\mathrm{S}-\mathrm{CH}_{2}\right), 3.87\left(3 \mathrm{H}, \mathrm{s}, \mathrm{O}-\mathrm{CH}_{3}\right), 3.42(3 \mathrm{H}, \\
\left.\mathrm{s}, \mathrm{O}-\mathrm{CH}_{3}\right)\end{array}$ \\
\hline 6 & $\mathrm{C}_{6} \mathrm{H}_{4} \mathrm{OCH}_{3}-4$ & & $173-175$ & $\mathrm{C}_{12} \mathrm{H}_{14} \mathrm{~N}_{4} \mathrm{O}_{2} \mathrm{~S}$ & 65 & $\begin{array}{l}\text { 7,09-7.92 }\left(4 \mathrm{H}, \mathrm{m}, \mathrm{C}_{6} \mathrm{H}_{4}\right), 4.43(2 \mathrm{H}, \mathrm{s}, \\
\left.\mathrm{S}-\mathrm{CH}_{2}\right), 3.85\left(3 \mathrm{H}, \mathrm{s}, \mathrm{O}-\mathrm{CH}_{3}\right), 3.34(3 \mathrm{H}, \\
\left.\mathrm{s}, \mathrm{O}-\mathrm{CH}_{3}\right)\end{array}$ \\
\hline 7 & $\mathrm{C}_{6} \mathrm{H}_{4} \mathrm{OCH}_{3}-4$ & & $170-172$ & $\mathrm{C}_{19} \mathrm{H}_{28} \mathrm{~N}_{4} \mathrm{O}_{2} \mathrm{~S}$ & 62 & $\begin{array}{l}\text { 7,1-7.87 }\left(4 \mathrm{H}, \mathrm{m}, \mathrm{C}_{6} \mathrm{H}_{4}\right), 4.07(2 \mathrm{H}, \mathrm{s}, \\
\left.\mathrm{S}-\mathrm{CH}_{2}\right), 3.90\left(3 \mathrm{H}, \mathrm{s}, \mathrm{O}-\mathrm{CH}_{3}\right), 3.70(2 \mathrm{H}, \\
\left.\mathrm{s}, \mathrm{O}-\mathrm{CH}_{2}\right), 1.50\left(12 \mathrm{H}, \mathrm{m},\left(\mathrm{CH}_{2}\right)_{8}\right), 1.01 \\
\left(3 \mathrm{H}, \mathrm{s}, \mathrm{CH}_{3}\right)\end{array}$ \\
\hline 8 & $\mathrm{C}_{6} \mathrm{H}_{2}\left(\mathrm{OCH}_{3}\right)_{3}-3,4,5$ & & $135-137$ & $\mathrm{C}_{14} \mathrm{H}_{18} \mathrm{~N}_{4} \mathrm{O}_{4} \mathrm{~S}$ & 72 & $\begin{array}{l}6.81\left(2 \mathrm{H}, \mathrm{s}, \mathrm{C}_{6} \mathrm{H}_{4}\right), 4.01\left(2 \mathrm{H}, \mathrm{s}, \mathrm{S}-\mathrm{CH}_{2}\right), \\
3.85\left(3 \mathrm{H}, \mathrm{s}, \mathrm{O}-\mathrm{CH}_{3}\right), 3.83(3 \mathrm{H}, \mathrm{s}, \\
\left.\mathrm{O}^{-} \mathrm{CH}_{3}\right), 3.70\left(3 \mathrm{H}_{1} \mathrm{~s}, \mathrm{O}-\mathrm{CH}_{3}\right), 3.47(3 \mathrm{H}, \\
\left.\mathrm{s}, \mathrm{O}-\mathrm{CH}_{3}\right)\end{array}$ \\
\hline 9 & $\mathrm{C}_{6} \mathrm{H}_{2}\left(\mathrm{OCH}_{3}\right)_{3}-3,4,5$ & & 200-201 & $\mathrm{C}_{16} \mathrm{H}_{22} \mathrm{~N}_{4} \mathrm{O}_{4} \mathrm{~S}$ & 83 & $\begin{array}{l}\text { 6.84 }\left(2 \mathrm{H}, \mathrm{s}, \mathrm{C}_{6} \mathrm{H}_{2}\right), 4.01\left(2 \mathrm{H}, \mathrm{s}, \mathrm{S}-\mathrm{CH}_{2}\right), \\
3.84\left(3 \mathrm{H}, \mathrm{s}, \mathrm{O}-\mathrm{CH}_{3}\right), 3.40(3 \mathrm{H}, \mathrm{s}, \\
\left.\mathrm{O}-\mathrm{CH}_{3}\right), 3.45\left(3 \mathrm{H}, \mathrm{s}, \mathrm{O}-\mathrm{CH}_{3}\right), 1.35(2 \mathrm{H}, \\
\left.\mathrm{t}, \mathrm{O}-\mathrm{CH}_{2}\right), 1.10\left(2 \mathrm{H}, \mathrm{m}, \mathrm{CH}_{2}\right), 0.95 \\
\left(3 \mathrm{H}, \mathrm{s}, \mathrm{CH}_{3}\right)\end{array}$ \\
\hline 10 & $\mathrm{C}_{6} \mathrm{H}_{2}\left(\mathrm{OCH}_{3}\right)_{3}-3,4,5$ & & $156-158$ & $\mathrm{C}_{17} \mathrm{H}_{24} \mathrm{~N}_{4} \mathrm{O}_{4} \mathrm{~S}$ & 80 & $\begin{array}{l}6.81\left(2 \mathrm{H}, \mathrm{s}, \mathrm{C}_{6} \mathrm{H}_{2}\right), 4.04\left(2 \mathrm{H}, \mathrm{s}, \mathrm{S}-\mathrm{CH}_{2}\right), \\
3.87\left(3 \mathrm{H}, \mathrm{s}, \mathrm{O}-\mathrm{CH}_{3}\right), 3.85(3 \mathrm{H}, \mathrm{s}, \\
\left.\mathrm{O}-\mathrm{CH}_{3}\right), 3.57\left(3 \mathrm{H}, \mathrm{s}, \mathrm{O}-\mathrm{CH}_{3}\right), 1.52(2 \mathrm{H}, \\
\left.\left.\mathrm{t}, \mathrm{O}-\mathrm{CH}_{2}\right), 1.52\left(4 \mathrm{H}, \mathrm{m}, \mathrm{CH}_{3}\right)_{2}\right), 0.90 \\
\left(3 \mathrm{H}_{1} \mathrm{~s}, \mathrm{CH}_{3}\right)\end{array}$ \\
\hline
\end{tabular}

1,2,4-triazol-3-ylthio) acetonitriles synthesized and their acetimidates (iminoethers) the intense singlets are fixed in the range of 3.81-3.87 $\mathrm{mp}$, which are the evidence of the presence of protons of the methoxy groups in the structure of all compounds [8].

One-proton singlets of the NH-group of $\mathrm{N}^{2}$ atom of the $1 \mathrm{H}-1,2,4$-triazole cycle at $13.48-13.55 \mathrm{mp}$ are also recorded. Proton signals of the aromatic ring of the compounds with the 4-methoxyphenyl radical are interpreted by multiplet signals in the range of 7.92-
$7.98 \mathrm{mp}$, unlike singlet signals of the aromatic ring of the compounds with 3,4,5-trimethoxyphenyl substituents, which are fixed at 6.83-6.84 mp. The ${ }^{1} \mathrm{H}$ NMRspectra are also characterized by the presence of the signal of protons of the methylene group in the range of 4.01-4.7 mp. The multiplet signals in the range of 0.90-3.46 mp confirm the presence of alkyl (alcohol) residues in iminoethers.

At the next stage of our research iminoethers (acetimidates) of 2-(5-(2-, 3-, 4-methoxyphenyl and 3,4,5- 
Table 2

Elemental analysis of the compounds synthesized

\begin{tabular}{|c|c|c|c|c|c|c|c|c|}
\hline \multirow{2}{*}{ Comp. No. } & \multicolumn{5}{|c|}{ Found, \% } & \multicolumn{4}{c|}{ Calculated, \% } \\
\cline { 2 - 9 } & $\mathrm{C}$ & $\mathrm{H}$ & $\mathrm{N}$ & $\mathrm{S}$ & $\mathrm{C}$ & $\mathrm{H}$ & $\mathrm{N}$ & $\mathrm{S}$ \\
\hline 1 & 53.64 & 4.09 & 22.75 & 13.02 & 53.66 & 4.16 & 22.70 & 13.07 \\
\hline 2 & 53.64 & 4.09 & 22.75 & 13.02 & 53.71 & 4.13 & 22.71 & 13.06 \\
\hline 3 & 53.64 & 4.09 & 22.75 & 13.02 & 53.71 & 4.18 & 22.71 & 13.06 \\
\hline 4 & 50.97 & 4.61 & 18.29 & 10.47 & 50.93 & 4.58 & 18.30 & 10.51 \\
\hline 5 & 51.78 & 5.07 & 20.13 & 11.52 & 51.82 & 5.09 & 20.11 & 11.49 \\
\hline 6 & 51.78 & 5.07 & 20.13 & 11.52 & 51.71 & 5.04 & 20.21 & 11.43 \\
\hline 7 & 60.61 & 7.50 & 14.88 & 8.52 & 60.64 & 7.53 & 14.84 & 8.50 \\
\hline 8 & 49.69 & 5.36 & 16.56 & 9.48 & 49.51 & 5.35 & 16.57 & 9.41 \\
\hline 9 & 52.44 & 6.05 & 15.29 & 8.75 & 52.41 & 6.07 & 15.32 & 8.71 \\
\hline 10 & 53.67 & 6.36 & 14.73 & 8.43 & 53.68 & 6.31 & 14.75 & 8.40 \\
\hline
\end{tabular}

trimethoxyphenyl)-1H-1,2,4-triazole-3-ylthio)acetatic acids were synthesized by saturation of 2-(5- $(2-, 3-$ 4-methoxyphenyl and 3,4,5-trimethoxyphenyl)-1H1,2,4-triazol-3-ylthio)acetonitriles with the flow of dry hydrogen chloride in the alcoholic medium when constant cooling the reaction mixture to $-5^{\circ} \mathrm{C}$.

It has been found by the method of HPLC/DAD-MS that the qualitative yield of the target product depends on the maintenance of the temperature mode of the reaction mixture. When increasing the temperature the discrete intensive peak of the impurity of the unreacted initial 2-(5- (2-, 3-, 4-methoxyphenyl, 3,4,5-trimethoxyphenyl)-1H-1,2,4-triazol-3-ylthio) acetonitrilerises is observed on the chromatograms (Fig. 3).

The reaction proceeds in two stages [9] - at the first stage imine chlorides of acids are formed when affecting the corresponding 2-(5-R-1H-1,2,4-triazol3 -ylthio)acetonitrile with hydrogen chloride. Then at the second stage the substitution of the alcohol residue for chlorine with formation of hydrochloride of the corresponding iminoether takes place (Fig. 4).

\section{Experimental Part}

2-(5-(2-, 3-, 4-methoxyphenyl, 3,4,5-trimethoxyphenyl)1H-1,2,4-triazol-3-ylthio)acetonitrile (1 - 4)

Method A. Boil the mixture of 0.01 Mole of 5-R1,2,4-triazol-3-thiol and 0.02 Mole of chloroacetonitrile in $50 \mathrm{~mL}$ of propanol for $20 \mathrm{~min}$ (or until the complete dissolution of thiol); add anhydrous sodium acetate to the reaction mixture after complete cooling. Filter the precipitate of 2-(5-(2-, 3-, 4-methoxyphenyl, 3,4,5-trimethoxyphenyl)-1H-1,2,4-triazol-3ylthio)acetonitrile, wash with diethyl ether and dry.

Method B. Boil the mixture of 0.01 Mole of 5-R1,2,4-triazol-3-thiol and $0.02 \mathrm{Mol}$ of sodium hydroxide in $50 \mathrm{ml}$ of propanol for 20 min (or until the complete dissolution of thiol); add 0.02 Mole of chloro-
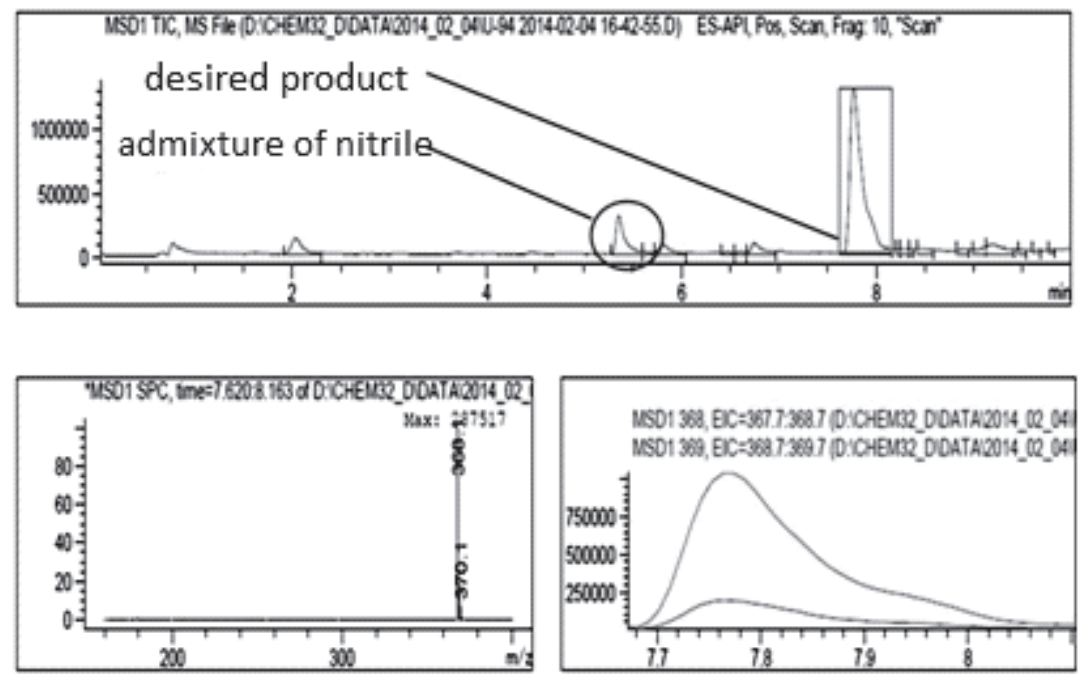

Fig. 3. The HPLC/DAD-MS-chromatogram of propyl-2-(5-(3,4,5-trimethoxyphenyl)-1H-1,2,4-triazole-3-ylthio)acetimidate obtained at the temperature of $2^{\circ} \mathrm{C}$ 


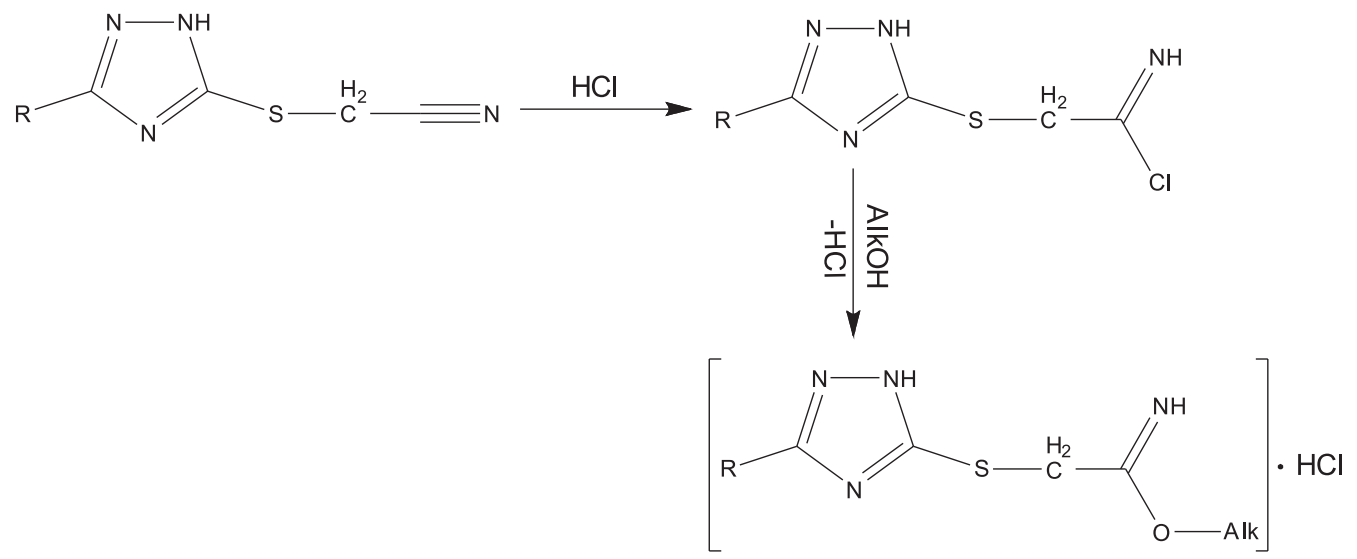

$\mathrm{R}=\mathrm{C}_{6} \mathrm{H}_{4} \mathrm{OCH}_{3}-2, \mathrm{C}_{6} \mathrm{H}_{4} \mathrm{OCH}_{3}-3, \mathrm{C}_{6} \mathrm{H}_{4} \mathrm{OCH}_{3}-4, \mathrm{C}_{6} \mathrm{H}_{2}\left(\mathrm{OCH}_{3}\right)_{3}-3,4,5$

Fig. 4. The scheme of obtaining 2-(5-R-1H-1,2,4-triazole-3-ylthio)acetimidates.

acetonitrile to the reaction mixture, boil the mixture for 20 min (until the neutral pH). Filter the primary precipitate of sodium chloride formed (from the solution heated). After complete cooling filter the precipitate of 2-(5 (2-, 3-, 4-methoxyphenyl, 3,4,5-trimethoxyphenyl)-1H-1,2,4-triazol-3-ylthio)acetonitrile formed, wash with diethyl ether and dry.

The yellowish crystalline substances obtained are soluble in alkaline solutions, as well as in organic solvents and solutions of mineral acids. For further analysis recrystallize these substances from ethanol.

Alkyl-2-(5-(2-, 3-, 4-methoxyphenyl, 3,4,5-trimethoxyphenyl)-1H-1,2,4-triazol-3-ylthio)acetimidate (5-9)

Place the solution of 0.01 Mole of 2-(5-(2-, 3-, 4methoxyphenyl, 3,4,5-trimethoxyphenyl)-1H-1,2,4triazol-3-ylthio)acetonitrile in $15 \mathrm{~mL}$ of chloroform and $25 \mathrm{~mL}$ of absolute alcohol into a Bunsen flask with the calcium chloride tube bound to its side tube. Close the flask with a stopper with the glass tube to the bottom of the flask connected to the drainage beakers. Cool the mixture in the desiccator filled with ice to the temperature of $-5^{\circ} \mathrm{C}$, and pass a flow of dry hydrogen chloride through the mixture, ultimately increment of hydrogen chloride is 2 mole with the excess of 1 mole related to the corresponding 2-(5-(2-, 3-, 4-methoxyphenyl, 3,4,5-trimethoxyphenyl)-1H1,2,4-triazol-3-iltio)acetonitrile. After saturation with hydrogen chloride leave the reaction mixture in the refrigerator at the temperature of $0^{\circ} \mathrm{C}$. On the second day the light brown crystals, which are soluble in organic solvents and poorly soluble in water, are precipitated. Wash the substance with diethyl ether and dry. For further analysis recrystallize these substances from ethanol.

The study of some physical and chemical properties of the compounds synthesized (Table 1) was performed by the methods described in the State Pharmacopoeia of Ukraine (SPhU, 1st ed.).The melting point was determined by the capillary method (SPhU, 1st ed., 2.2.14) on a PTP(M) apparatus.

The molecular mass of substances and the presence of impurities were determined by the method of high-performance liquid chromatography under such conditions:

- device - Agilent 1260 Infinity HPLC System;

- software - OpenLAB;

- column - $\varnothing 4,6 \times 30 \mathrm{~mm}$, reversible phase Zorbax SB C18, 1,8 $\mu \mathrm{m}$;

- column temperature $-40^{\circ} \mathrm{C}$;

- eluent $\mathrm{A}-\mathrm{H}_{2} \mathrm{O}-0.1 \% \mathrm{HCOOH}$;

- eluent $\mathrm{B}-\mathrm{CH}_{3} \mathrm{CN}-0.1 \% \mathrm{HCOOH}$;

- flow rate $-400 \mu \mathrm{L} / \mathrm{min}$;

- gradient - linear from $5 \%$ to $100 \%$ of eluent B for $15 \mathrm{~min}$;

- detector:

1) diode array $\left(\lambda_{1}=210 \mathrm{~nm} ; \lambda_{2}=254 \mathrm{~nm}\right)$;

2) Agilent 6120 single-quadrupole mass-spectrometer: ion source - API-ES; positive polarity; SIM mode; fragmentator - $10 \mathrm{~V}$; drying gas - nitrogen (temperature $-300^{\circ} \mathrm{C}$, rate $-10 \mathrm{~L} / \mathrm{min}$ ); nebulizer pressure 40 psig; scanning in the range of $\mathrm{m} / \mathrm{z} 160-1000$.

The elemental composition of new compounds (Table 2) was determined using an ELEMENTAR vario EL cube elemental analyzer (sulfonamide as the standard).

${ }^{1} \mathrm{H}$ NMR spectra were recorded on a Varian VXR300 spectrophotometer of nuclear magnetic resonance (DMSO- $\mathrm{D}_{6}$ as a solvent, tetramethylsilane as the internal standard); the data were decoded with the ADVASP 143 software.

\section{Conclusions}

1. With the aim of further study of 1,2,4-triazoles with 2-, 3-, 4-methoxyphenyl, 3,4,5-trimethoxyphenyl substituent 10 new compounds have been synthesized.

2. For all compounds the preliminary biological screening has been carried out using the PASS ONLINE software.

3. The optimal synthetic conditions have been selected with the help of modern physical and chemical methods of analysis.

4. Individuality of the compounds synthesized has been determined, and their structure has been proven. 


\section{References}

1. Georgievskiy G. V. Farmakom, 2006, No.3, pp.27-31.

2. Xu Liang-Zhong, Zhou Kai, Hu Zhi-Qiang, Bi Wen-Zhao. Chem. Res. Chin. Univ., 2006, No.22 (6), pp.765-767.

3. El-Barbary A. A., Abou-El-Ezz A. Z., Abdel-Kader A. A. et al. Phosp., Sulfur and Silicon and Relat. Elem., 2004, No.179 (8), pp.1497-1508.

4. Kaplaushenko A. G., Gotsulia A. S., Panasenko O. I., Knysh Ye. G. Farmatsevtychnyi zhurnal - Pharmaceutical Journal, 2009, No.5, pp.83-87.

5. Kaplaushenko A. G., Panasenko O. I., Knysh Ye. G. Farmatsevtychnyi chasopys - Pharmaceutical Review, 2007, No.1, pp.32-35.

6. Kaplaushenko A. G., Knish E. G., Panasenko A. I. Pharmaceutical annals, 2007, No.1, pp.32-35.

7. Samelyuk Y. G., Kaplaushenko A. G. Current issues of pharmaceutical and medical science and practice, 2013, No.2, pp.125-128.

8. Gunther H. NMR Spectroscopy: basic principles, concepts, and applications in chemistry, Weinheim: Wiley-VCH, 2013, 718 p.

9. Zilberman E. N. Reaktsii nitrilov - Reactions of nitriles, Moscow: Himiya, 1972, 448 p.

Надійшла до редакції 29.07.2015 р. 